\title{
14
}

\section{Labour policies in a deflationary environment}

\author{
Annamaria Simonazzi
}

\section{Introduction}

National models of employment, production and welfare both mediate and respond to multiple pressures for change associated with various external and internal challenges: increased globalisation, deregulation and financialisation of markets, technological change, the ageing of the population and migration flows. The analysis of these challenges, their effect 'in maintaining, reshaping, revitalizing or indeed destabilizing national employment models', as well as the interlocking nature of institutions has been at the centre of Jill Rubery's research (Bosch, Lehndorff and Rubery, 2009: 2). The possibility of spillover or domino effects from employment to welfare, family and the production spheres increases the scope of change and suggests the need for a multifaceted approach involving macroeconomic, labour and social reproduction objectives (Rubery, 2015).

The Eurozone crisis has rekindled the debate on how to respond to shortand long-term change and to the hardships that it produces. The countries worse hit by the sovereign debt crises, in particular, have been the targets and laboratory of an unprecedented interventionism in the sphere of labour and industrial relations. ${ }^{1}$ A problem of competitiveness, and specifically of labour cost competitiveness, has been diagnosed for their illness, hence the need for 'employment friendly reforms' to spur productivity and competitiveness. Labour and welfare reforms inflicted on, or self-inflicted by, various countries have been pursued within a deeply recessionary macro-environment. Indeed, internal devaluation has become a functional substitute for currency devaluation, and austerity-oriented fiscal policies are used to complement and 
reinforce the structural reforms. Consequently, the landscape of industrial relations has deeply changed and the 'European social acquis', rooted in social dialogue and public systems of social protection, is everywhere in retreat. A 'toxic austeritarism' (Hyman, 2015) 'has left little or no margin for domestic democratic institutions and social actors, downgraded from political to executive subjects' (Leonardi, 2016).

The long crisis and the policies that have been implemented in response raise questions that transcend a single country to encompass the European institutions. This chapter addresses two issues, analysed from the point of view of the Italian case. The first, relates to the increasing inequality in the labour market. As observed by Rubery (2015: 2), mainstream economics' failure to find a 'direct correlation between regulation and macro employment performance and growth ... changed the terms from performance to social justice issues ... [E]mployment regulation was still considered harmful because it favoured insiders over outsiders.' In Italy, the increasing dualism of the labour market has been depicted as an insider-outsider problem, created by the 'excessive' protection of standard employment relations. Consequently, the recent legislation aimed at reducing the regulation of the labour market has been presented as a necessary step towards greater equality. The second issue relates to the search for viable models to address the challenges of technological change in a globalised and competitive environment. Here again, the decade-long stagnation of Italian productivity has been ascribed to the insufficient flexibility and excessive protection of the labour market. This chapter also contrasts the short-term competitiveness effects of austerity/flexibility policies with the long-term efficiency effects deriving from a greater commitment of both the employer and the employed workforce. The view of social policy as a productive factor is embedded in the conviction that sustained growth and decent working conditions are the result of the interactions between macro-policies and labour outcomes, and great risks can spring from neglecting the systemic consequences of generalised, panEuropean austerity.

\section{The construction of a dualistic labour market}

We can distinguish three phases in the development of Italy's labour policies in recent decades. In the first, in the early 1990s, agreements were targeted mainly at achieving wage flexibility; in the second, from the mid-1990s to the mid-2000s, legislation aimed at increasing labour market flexibility through the liberalisation of a wide range of atypical contracts; since then, and especially since 2011, the legislation turned to target the 'dualism' in the labour market. 
Until the outbreak of the crisis, labour market reforms in Italy had mostly targeted new hirings (the so-called flexibility at the margin), while the firing rules for regular contracts were left substantially untouched. This policy was originally justified as a means of promoting the participation of youth and other hard-to-employ to the labour market (Rubery and Piasna, 2016). Between 1995 and 2007, despite a mediocre rate of growth of GDP, more than 3 million jobs were created (what has been called growth-less job creation), with flexible employment, characterised by fixed-term contracts, involuntary part-time and bogus self-employed, accounting for most of it. On top of these, and often intermingled with them, Italy also witnessed a great number of informal workers in the shadow economy. New hiring has taken place mainly through temporary work contracts, and the share of youth in temporary contracts is significant (Figure 14.1). At the end of 2012, only 21 per cent of new hiring contracts were open-ended, while 58 per cent were fixed-term, 9 per cent collaboration contracts, ${ }^{2} 3$ per cent apprenticeship contracts and other precarious contracts (temporary work agencies) accounted for the remaining 9 per cent (Table 14.1). In an economic slowdown, precarious workers are the first to be made redundant, though workers with an open-ended contract are far from shielded.

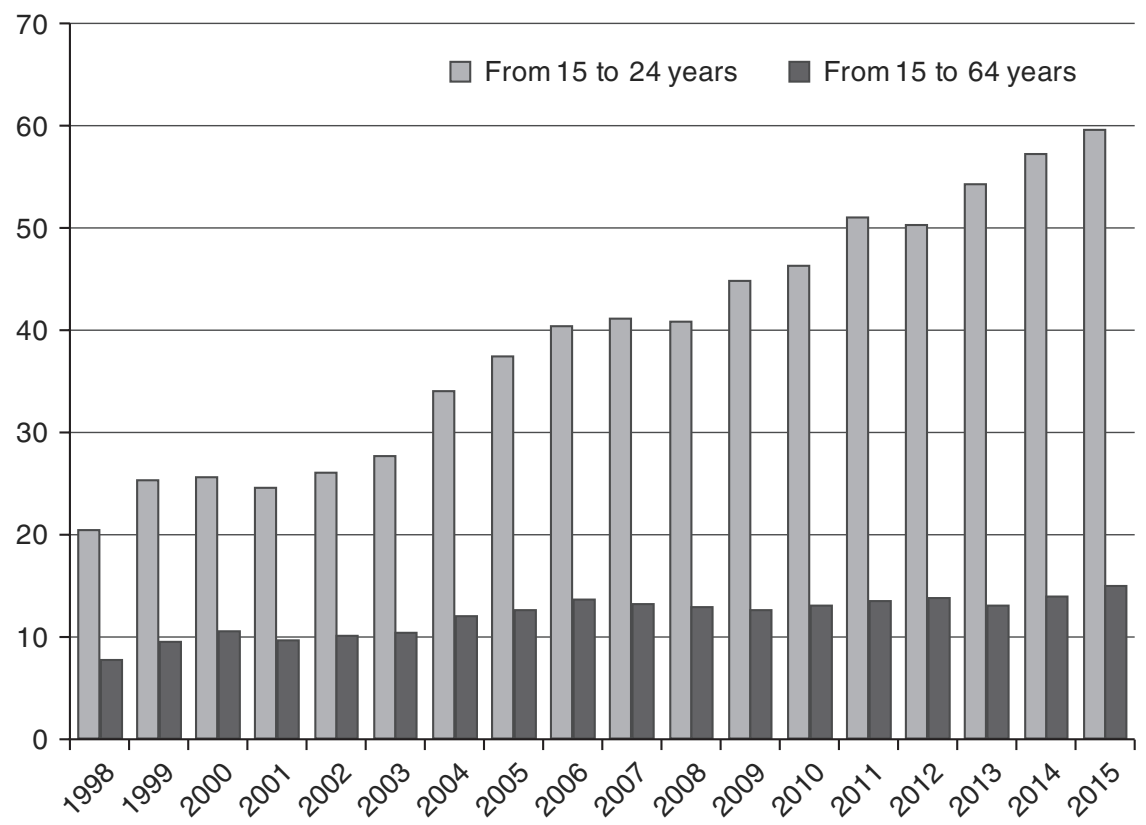

Figure 14.1 Share of temporary employment in total Italian employment by age group, $1998-2005(\%)$

Source: Fana et al. (2016). 
Table 14.1 Hiring and firing by type of contract, 2012

\begin{tabular}{lrrrrr}
\hline & \multicolumn{2}{c}{ Hiring } & & \multicolumn{2}{c}{ Firing } \\
\cline { 2 - 3 } \cline { 6 - 6 } & Number & \% & & Number & \multicolumn{1}{c}{$\%$} \\
\hline Premanent contracts & $1,788,830$ & 20.9 & & $2,202,341$ & 25.3 \\
Temporary contracts & $5,011,019$ & 58.4 & & $4,664,905$ & 53.6 \\
Apprenticeships & 277,496 & 3.2 & & 211,828 & 2.4 \\
Collaboration contracts & 756,582 & 8.8 & & 832,111 & 9.6 \\
Other & 745,247 & 8.7 & & 791,384 & 9.1 \\
Total & $\mathbf{8 , 5 7 9 , 1 7 4}$ & $\mathbf{1 0 0 . 0}$ & & $\mathbf{8 , 7 0 2 , 5 6 9}$ & $\mathbf{1 0 0 . 0}$ \\
\hline
\end{tabular}

Notes: 'Other' includes agency contracts and job on call also in the public sector.

Source: ILO (2015).

Since the mid-2000s, labour policies moved in somewhat contradictory ways; they aimed at reducing the dualism in the labour market by reducing the firing costs of open-ended contracts and promoting, through regulation and subsidies, the conversion of certain types of atypical contracts, while, at the same time, favouring the growth of other non-standard forms of employment.

Under the concurrent pressure of the markets and EU governors, ${ }^{3}$ the Monti government launched the first attack on the protection of regular employment. The Legge Fornero (Law 92/2012) of 2012 aimed at addressing labour market dualism by acting on the firing and hiring costs of different types of contracts. On the one hand, it reduced the cost of individual dismissal, weakening the effectiveness of the 'Articolo 18' of Law 300/1970, which regulates firing conditions on open-ended contracts $;^{4}$ on the other, it tried to limit employers' use of 'false' self-employment and 'collaboration contracts' and to create incentives for the greater use of apprenticeship contracts. Finally, it reformed the system of unemployment benefits, extending the coverage to some forms of precarious contracts.

In 2014, Law $78 / 2014$ (Decreto Poletti) removed the need to justify the use of fixed-term contracts, while still maintaining some limitations: a firm could not have more than 20 per cent of its total workforce on a fixed-term contract, ${ }^{5}$ and each contract could only be renewed for a maximum of three years.

Finally, in 2015, the Renzi government adopted two different policies that also aimed to reduce labour market dualism and foster 'regular' employment by acting on two fronts: lowering firing costs of open-ended contracts and providing a generous subsidy for permanent hiring. Firstly, a broad-ranging enabling law (the so-called Jobs Act) involved the regulation governing dismissals, simplification of contracts and labour law procedures, reformed unemployment 
benefits and active and passive labour market policies, and improved reconciliation between work and family life. The Jobs Act abolished workers' reinstatement rights in case of dismissal (except for discriminatory reasons), replacing it with a monetary compensation (amounting to two months' pay per year of work, reduced to half for firms with less than 15 employees). It introduced a new standard open-ended contract for new hires, which reduces the level and the uncertainty of firing costs for all new permanent contracts in firms with at least 15 employees (the 'contratto a tutele crescenti', or 'graded security contract'). Finally, while eliminating some forms of atypical contracts, such as project work contracts, it increased the maximum amount of revenues that can be received in vouchers from $€ 5,000$ to $€ 7,000$ per year, thereby de facto incentivising the most precarious type of contract (see Chapter 8). Secondly, a measure passed in the 2015 Budgetary Law provides a sizeable temporary rebate of non-wage labour costs (up to $€ 8,060$ per year for three years) to new permanent hiring of workers who, in the previous semester, did not hold an open-ended position. These incentives are not targeted to specific groups of workers, nor are they contingent upon firm-level net job creation, that is, firms can use the subsidy to convert a temporary contract into a permanent one.

Assessment of the success of the new law is necessarily still preliminary. Using microdata for Veneto, Sestito and Viviano (2016) conclude that the two measures contributed to double the monthly rate of conversion of fixedterm jobs into permanent positions. However, around 40 per cent of the new total gross hires with open-ended contracts occurred because of the incentives, whereas 5 per cent can be attributed to the new firing regulations. Fana and colleagues (2016) also find that the increase in permanent contracts was mostly due to the conversion of temporary contracts into permanent ones. Excluding transformations, new permanent contracts (net of dismissals) were only 20 per cent of the total contracts activated during the first nine months of 2015, with a high share of involuntary part-time contracts. A dominant effect of fiscal incentives, especially for big firms, is also detected by the analysis of the Central Statistical Office (Istat, 2016: 190-3). If the new firing rules made firms less reluctant to offer permanent job positions to yet untested workers, the opportunity of benefiting from the incentives in case of a conversion certainly boosted temporary hiring, which came to be concentrated at the very end of the period set for claiming the subsidy. The high rate of subsidised conversions also raises the issue of the size of the dead-weight loss implicit in these subsidies. 


\section{The insider-outsider debate}

Flexibility policies were first advocated as the necessary response to the low job creation of the 1980s. In those years, 'jobless growth' and 'Eurosclerosis' were imputed to the rigidity of the labour market. Deregulation, it was argued, would lead to a net creation of jobs. Similarly, ten years later, the 'growth-less job creation' was credited to the labour market reforms. A lively debate on the employment effects of employment protection legislation (EPL) has accompanied these reforms. If the 1994 Organisation for Economic Co-operation and Development (OECD) Jobs Study (OECD, 1994) concluded that job creation relies on efficient markets, free from institutional constraints, ten years later the 2004 OECD Employment Outlook drew more cautious conclusions. Noticing the general tendency of labour policies towards 'easing the recourse to temporary forms of employment while leaving existing provisions for regular or permanent employment practically unaltered' (OECD, 2004: 63), the report concluded that the net impact on employment is ambiguous. In fact, EPL leads to two opposite effects: it reduces exits from the labour market while making entry more difficult. Thus, it concluded, employment cannot increase without economic growth, but differences in the strictness of EPL for regular and temporary jobs respectively might lead to the rise in the incidence of temporary work for groups in a weaker labour market position, such as youth, prime-age women and low-skilled workers. In view of this, facilitating the use of temporary employment while not changing EPL for regular employment may aggravate labour market duality and negatively affect the career and productivity of those trapped in temporary jobs.

Of the two options to reduce dualism - increase protections for temporary workers or reduce protections for regular employment - eventually the latter prevailed in Italy. With dualism worsening, the debate about increasing inequalities in the labour market intensified. Various arguments, ranging from the insider-outsider to the intergenerational conflict, have converged on attributing the precariousness of the 'outsiders' to the protection of the 'insiders' and have thus been instrumental in orienting the policies towards the reduction of protection. After decades of policies aimed at reducing the supposed rigidity of the labour market, compounded by austerity measures implemented in the crisis, the increasing precariousness of ever-greater segments of the workforce produced by these policies has been used to argue for the need to eliminate the excessive protection of insiders that unfairly discriminates against outsiders.

Yet was the Italian labour market as rigid as commonly maintained? The indicators of labour turnover have never validated the official accounts of an 
overly rigid Italian labour market. Research on turnover had demonstrated the co-existence of a very high index of turnover with a high share of job positions with long tenure. Contini and Trivellato (2005) argued that this apparently contradictory evidence could be explained by the dichotomy between two different models of employment - extremely mobile and extremely stable workers - that were combined in the index. While the youth account for most of the turnover, there are also plenty of workers in other age brackets in perennial flux. Among them, women, low-educated people and employees in small firms, low-tech segments of the value chain or traditional reservoirs of irregular work (agriculture, commerce, construction, services). These workers experience long spells of unemployment, often longer than the periods spent in employment. Core workers' protection had to do more with professional skills, experience and the firm's specific capabilities, making them valuable to the firm, than with EPL. As labour market segmentation theory has long made clear, multiple factors lead to the differentiation of employment conditions and rewards and it is worker-capital divisions, rather than employment regulation, which are the main source of inequalities in the labour market (Rubery and Piasna, 2016).

With increasing competition from low-cost countries in 'mature' products, and the swift path of technological change, even core male workers employed in sectors no longer protected from competition have come to be increasingly exposed to the risk of dismissal and unemployment (Istat, 2016: 129). Meanwhile, the protection of regular employment has been gradually eroded. An indication of the decreasing degree of rigidity of the labour market is provided by the OECD index of EPL (to be interpreted with caution owing to doubts about the reliability of the indicator). The index for Italy fell from 3.82 in 1990 to 2.26 in 2013, and compares not too unfavourably with an index of 2 for Germany and 3 for France (Table 14.2). Firing difficulties, which have a great weight in the indicator, have been further reduced in 2015 (as explained in the previous section). Moreover, thanks to a policy approach of levelling-down equalisation, in

Table 14.2 Employment protection legislation (OECD index), selected countries 1990; 1992; 2007; 2013

\begin{tabular}{lllllll}
\hline & Italy & France & Germany & Spain & Portugal & Greece \\
\hline 1990 & 3.82 & 2.7 & 2.92 & 3.65 & 4.1 & 3.62 \\
1999 & 3.19 & 2.98 & 2.34 & 2.8 & 3.7 & 3.62 \\
2007 & 2.38 & 3.05 & 1.93 & 2.68 & 3.49 & 2.62 \\
2013 & 2.26 & 3 & 2 & 2.31 & 2.5 & 2.07 \\
\hline
\end{tabular}

Source: OECD (2017). 
Table 14.3 Index of protection for open-ended contracts (EPRC) and ratio of temporary contracts (EPT) over EPRC, 2013

\begin{tabular}{lllllll}
\hline & Italy & France & Germany & Spain & Portugal & Greece \\
\hline EPRC & 2.79 & 2.82 & 2.98 & 2.28 & 2.69 & 2.41 \\
EPT/EPRC & 0.97 & 1.33 & 0.59 & 1.39 & 0.87 & 1.21 \\
\hline
\end{tabular}

Notes: Employment protection for regular contracts (EPRC); Employment protection for temporary contracts (EPT).

Source: OECD (2017).

2013 the index no longer indicates the existence of dualism in the Italian labour market (Table 14.3). The striking difference with Germany may be due to both the reduced protection of regular employment in Italy and the great increase in the precariousness of the secondary labour market in Germany.

What can be concluded from the results achieved by labour market deregulation in terms of employment and growth? One tenet of labour market segmentation theory is that flexibility is much more easily achieved by policies that support growth, when job opportunities are plenty and workers move between jobs. Data on gross labour turnover (hiring and firing) confirm this proposition. Labour turnover in Italy was high at the beginning of the last decade before the reforms that tackled insiders' protection, but in fact fell during the crisis when turnover mostly involved dismissals (Table 14.4). Once dismissed, adult workers face greater difficulties in re-entering the labour market (Simonazzi and Villa, 2007). The absence of effective retraining and activation policies makes these workers subject to the loss of human and social capital, increasing the risk of long-term unemployment; in 2015, 68.4 per cent of total adult unemployed were unemployed for more than 12 months, compared to 55.5 per cent of unemployed youth (Istat, 2016: 133). The absence of a correlation between labour market flexibility and macroeconomic employment performance raises the question of the social and long-term (growth) effects of these policies.

\section{Inequalities, unemployment, precariousness, poverty}

\section{Job quality}

The deep and prolonged economic crisis has taken a toll on the labour markets, with a fall in employment rates, dramatic increases in unemployment 
Table 14.4 Gross turnover (hiring and firing/ quitting) by firm size and region - Italy, manufacturing

\begin{tabular}{llllllllll}
\hline & Total & $\mathbf{2 0 - 4 9}$ & $\mathbf{5 0 - 1 9 9}$ & $\mathbf{2 0 0 - 4 9 9}$ & $\begin{array}{l}\text { Over } \\
\mathbf{5 0 0}\end{array}$ & $\begin{array}{l}\text { North- } \\
\text { West }\end{array}$ & $\begin{array}{l}\text { North- } \\
\text { East }\end{array}$ & Centre & South \\
\hline 2003 & 29.9 & 34.2 & 30.6 & 27.4 & 25.8 & 23.8 & 31.5 & 30.0 & 34.2 \\
2004 & 26.1 & 25.5 & 27.7 & 24.8 & 25.7 & 20.9 & 29.2 & 28.3 & 37.2 \\
2005 & 24.0 & 25.4 & 24.4 & 23.2 & 22.3 & 18.3 & 24.7 & 26.7 & 35.3 \\
2006 & 25.7 & 26.5 & 27.0 & 24.3 & 23.8 & 20.7 & 26.1 & 27.7 & 37.0 \\
2007 & 26.9 & 26.1 & 29.8 & 27.5 & 24.2 & 22.0 & 28.6 & 30.3 & 38.8 \\
2008 & 24.1 & 23.5 & 25.5 & 23.2 & 23.3 & 20.1 & 24.9 & 26.4 & 34.6 \\
2009 & 17.5 & 17.4 & 19.2 & 17.0 & 16.1 & 15.2 & 17.0 & 17.8 & 28.0 \\
2010 & 18.8 & 18.9 & 20.4 & 19.4 & 16.5 & 15.9 & 19.4 & 18.2 & 27.7 \\
2011 & 18.5 & 19.3 & 19.7 & 17.7 & 16.7 & 15.5 & 18.4 & 18.2 & 27.3 \\
2012 & 17.2 & 17.8 & 18.8 & 15.4 & 15.8 & 14.2 & 16.5 & 18.3 & 27.3 \\
2013 & 16.1 & 16.4 & 16.8 & 14.0 & 16.2 & 13.0 & 16.2 & 16.5 & 25.2 \\
\hline
\end{tabular}

Source: Checchi and Leonardi (2015) on Bank of Italy data.

and its duration. Between 2007 and 2014 unemployment doubled, from 6 to 13 per cent, only partly mitigated by a massive use of short-time schemes and wage redundancy funds. Employment and inactivity rates are now among the worst of the whole EU. While employment conditions have worsened especially for youth, deterioration is common to all age groups. The unemployment rate, which has increased across all age groups, reached a peak of 35.5 per cent in the 15-24 age bracket and is 9.7 per cent for the traditional male breadwinner category (the age bracket 35-49) (Table 14.5). The number of NEETs is also especially worrying: 2.3 million aged 15-29 in 2015, 96 per cent of which are in the age bracket 18-29. Their share increased from 17.7 per cent in 2008 to 25 per cent in 2013 (down to 22.3 per cent in the second quarter of 2016) (Istat, 2016b: 115).

The crisis has also affected those who remained in employment, remarkably worsening the quality of existing jobs and the level of pay. The OECD has developed a framework to assess the quality of jobs, structured around three main dimensions: earnings quality, labour market security and quality of the working environment. It is no wonder that all programme/crisis countries - Estonia, Greece, Hungary, Italy, Poland, Portugal, the Slovak Republic, Spain - do relatively badly in two or all of the three dimensions of job quality, and none performs well in at least one of these dimensions (OECD, 2016). Conversely, Germany and the Nordic countries are among the best performers (at least two out of three dimensions). Outcomes on job quality across socio-economic groups 
Table 14.5 Employment and unemployment rates by sex, area, age, citizenship and education, 2016

\begin{tabular}{|c|c|c|c|c|c|c|}
\hline & \multicolumn{3}{|c|}{ Employment rate (\%) } & \multicolumn{3}{|c|}{ Unemployment rate $(\%)$} \\
\hline & Total & Male & Female & Total & Male & Female \\
\hline Total & 57.7 & 66.9 & 48.5 & 11.5 & 10.6 & 12.8 \\
\hline \multicolumn{7}{|l|}{ Area } \\
\hline North & 66.3 & 73.8 & 58.8 & 7.4 & 6.5 & 8.6 \\
\hline Centre & 62.3 & 70.6 & 54.3 & 10.4 & 9.4 & 11.6 \\
\hline South & 44.0 & 56.1 & 32.1 & 19.3 & 17.6 & 22.1 \\
\hline \multicolumn{7}{|l|}{ Age } \\
\hline $15-34$ & 40.6 & 46.3 & 34.7 & 21.4 & 20.2 & 22.9 \\
\hline $15-24$ & 17.2 & 19.5 & 14.7 & 35.5 & 35.1 & 36.1 \\
\hline $25-34$ & 61.0 & 70.2 & 51.7 & 16.9 & 15.4 & 18.9 \\
\hline $35-49$ & 72.8 & 83.7 & 62.1 & 9.7 & 8.3 & 11.5 \\
\hline $50-64$ & 58.3 & 70.0 & 47.2 & 6.2 & 6.2 & 6.2 \\
\hline \multicolumn{7}{|c|}{ Citizenship } \\
\hline Italian & 57.5 & 66.5 & 48.4 & 11.1 & 10.4 & 12.2 \\
\hline Foreign & 59.5 & 71.1 & 49.3 & 15.0 & 13.0 & 17.4 \\
\hline \multicolumn{7}{|l|}{ Education } \\
\hline Primary & 43.1 & 55.3 & 29.7 & 15.8 & 14.4 & 18.5 \\
\hline Diploma & 64.6 & 73.9 & 55.4 & 10.8 & 9.4 & 12.5 \\
\hline Graduate & 78.6 & 83.6 & 74.8 & 6.2 & 5.0 & 7.2 \\
\hline
\end{tabular}

Source: Istat (2016b).

confirm the evidence on labour market inequalities. The worse off are youth and low-skilled workers. Not only do they have the poorest performance in terms of employment and unemployment rates, but they also have the worst outcomes with respect to job quality: lower earnings quality, considerably higher labour market insecurity and higher job strain (especially the low-skilled).

The dynamics of wage inequality depicted in the OECD job quality index must be seen against a context of falling 'average' earnings. Additionally, most of the jobs lost during the crisis were predominantly low-paid (Istat, 2015: 157). These two factors result in a deceptive increase in earnings quality. In effect, like all other 'crisis' countries (but also the UK, see Blundell et al., 2014), between 2010 and 2016 Italy suffered a reduction in real wages (Figure 14.2). An important factor has been the increasingly low levels of entry wages for newly hired young workers, due to the diffusion of atypical and apprenticeship contracts for first-job seekers (Figure 14.3). There is a persistent wage penalty, of the order of 11 per cent, associated with working under a temporary contract. Checchi 


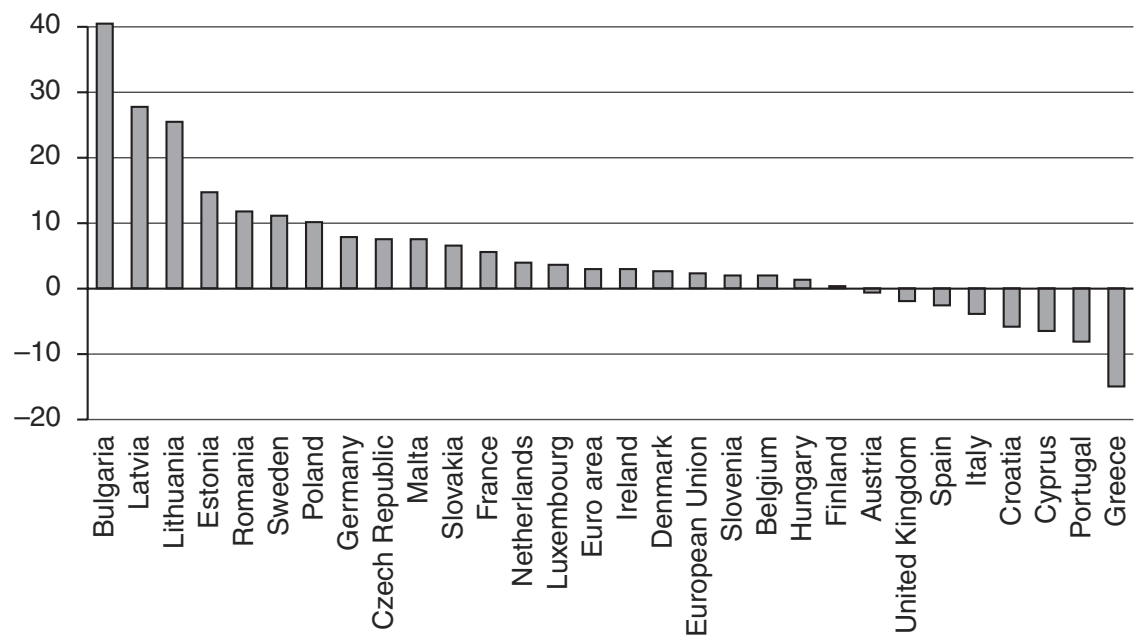

Figure 14.2 Development of real wages, 2010-16(\%)

Source: AMECO Database. Consumer Price deflator.

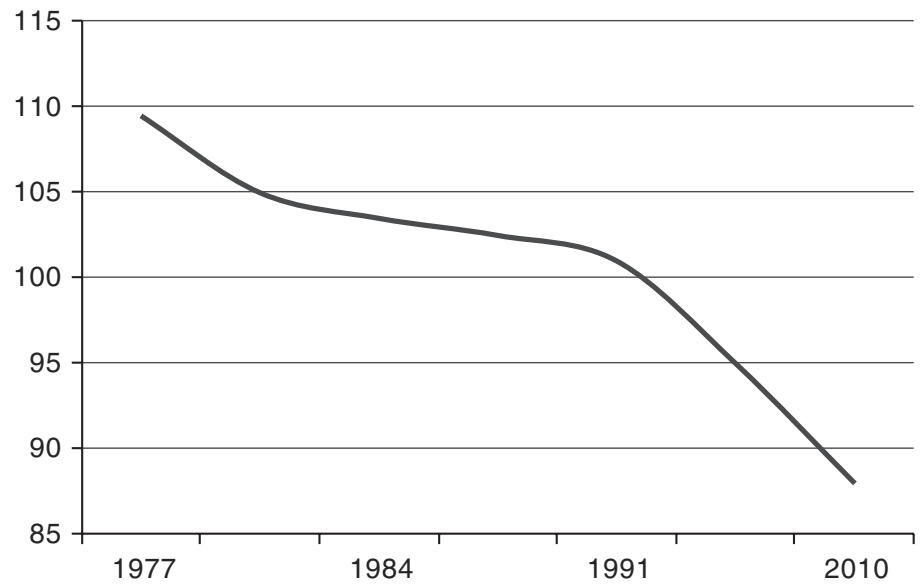

Figure 14.3 Relative wage of 30 year olds to average wage - Italy (\%)

Source: Checchi and Leonardi (2015), based on Bank of Italy survey on household incomes.

and Leonardi (2015) have estimated that it mostly affects workers in the two bottom quintiles, while workers in the top quintile are less penalised. Moreover, this penalty is halved when individual fixed effects are included, suggesting that labour market flexibility increases wage differentials partly by sorting individuals according to their unobservable characteristics and partly by changing the wage 
for less-qualified occupations. This indicates that there are at least two types of temporary workers: the 'professionals', who take advantage of temporary contracts to increase their market power by enlarging the set of potential employers; and the 'precarious', who do not succeed in achieving a permanent job because they do not have the abilities demanded in the labour market. This same difference determines the probability to move out of a temporary contract to an openended one. Checchi and Leonardi conclude that whenever a legislative reform expands the share of workers under temporary contracts then, other things being constant, an increase in earnings inequality should be expected.

\section{Welfare state retrenchment}

The deregulation of the labour market ('flexibility at the margin') has been accompanied by partial reform of the so-called 'shock absorber' systems. A truly universal unemployment benefit scheme and income-support schemes are still in the making in Italy. The existing unemployment benefit system is based on two pillars: the unemployment benefit (divided into ordinary and reduced contributions) and the cassa integrazione (a short-time work scheme that keeps the worker attached to the firm, divided into ordinary, extraordinary and exceptional). The Fornero reform improved the first pillar, addressing two structural issues of the unemployment insurance benefits system: the low level and the short duration of benefits for workers on standard contracts, and the low coverage of workers with non-standard contracts. For workers on standard contracts the reform increased the replacement rate to 75 per cent of the previous wage and the maximum duration to 12 months (and to 18 months for those over 55), leaving unchanged at 52 full-time weeks the eligibility conditions. For workers on non-standard contracts, the replacement rate was increased to 75 per cent of the wage for a maximum duration of half the number of weeks of contributions. Eligibility criteria were reduced to 13 weeks of contributions in the previous 12 months. As a result, the number of workers covered increased by about 800,000 between November 2012 and November 2013. Nevertheless, the reform left other aspects of the system unchanged, such as the lack of social assistance available to jobseekers who have exhausted the eligibility period for unemployment benefits (ILO, 2015). As for the second pillar, the reform slightly revised eligibility conditions and involved the social partners, through the bilateral funds, in the funding of the benefit extended to all firms with more than 15 employees. The Jobs Act further revised the unemployment insurance system, setting new conditions for the renamed unemployment benefit (NASPI), a new provision (ASDI) to cover unemployed workers in distressed economic conditions who had exhausted the period (up to 18 months) of normal unemployment benefit, 
and a special benefit covering atypical workers ('collaborators', as defined in Note 2) (DIS-COLL). ${ }^{6}$

Active labour market policies (ALMPs) have always had a secondary role in Italy. With the crisis, the traditional difficulty in running efficient Public Employment Services (PES) and activation programmes for jobseekers has proved challenging. Thus Italy prioritised hiring incentives, which are easy to implement, even though in most cases the literature identifies significant deadweight losses associated with this type of programme. Consequently, most ALMPs consisted in introducing and/or modifying the eligibility requirements for employment subsidies, according to what were deemed the categories of worker in most need of employment opportunities at that particular time (ILO, 2015: 61-70). These policies contrast with empirical results suggesting that employability of dismissed workers increasingly relies on both training and availability of jobs. The same report emphasises the point that no ALMP, no matter how efficient, can work if the economy is not growing. Since reforms in the labour market have been accompanied by draconian cuts in the budget, little room has been left for compensatory, active or passive, labour policies or welfare expenditure. Budget constraints were added to the notorious scarce efficiency of PES in reallocating labour towards equally scarce job opportunities. In an ever-deteriorating macroeconomic context, increased flexibility could do little to counteract the massive unemployment created by the crisis and the subsequent austerity policies. That is why, starting from these premises, it is difficult to speak of 'security'.

\section{Pension reform}

At the peak of the crisis, the Monti government also implemented a pension reform, which increased the minimum retirement age to 66 years, eliminating all forms of flexibility. Having fixed the calculation of pension benefits strictly according to contributions paid, it introduced an unnecessary rigidity with regard to retirement age. Precipitously and rigidly applied to respond to the urgent need to reduce spending and appease the financial markets (and the EU and German authorities), this reform left several short-term and longterm problems open. If, according to international assessment (International Monetary Fund and World Bank), after the Fornero reform the Italian pension system had become the most rigorous of EU systems, it was also the least adequate in terms of pension income and the most ineffectual with respect to the broader objectives of productivity, growth and employment. Two main tradeoffs, which derive from the interrelation between the pension system, the labour market and the welfare state, threaten its long-term sustainability. Firstly, by 


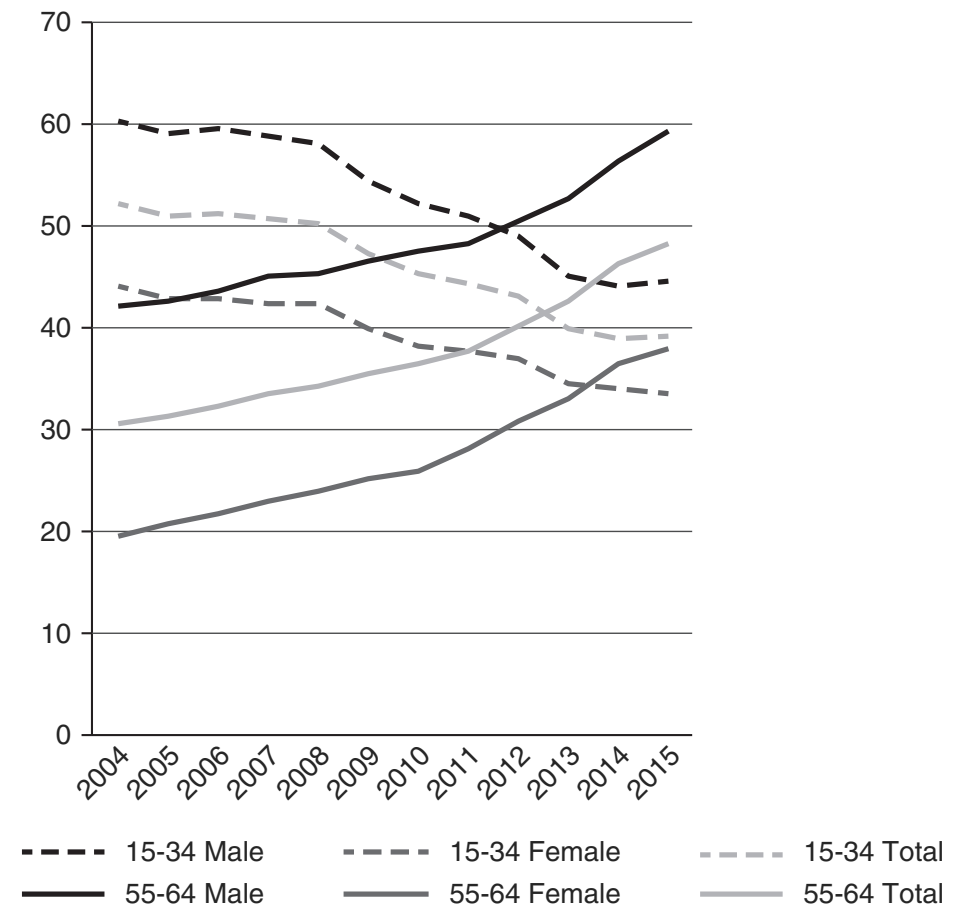

Figure 14.4 Employment by age and gender, 2004-15 (\%)

Source: Istat (2016: 132).

increasing the retirement age among older workers, the reform had a negative effect on youth unemployment (Figure 14.4). By slowing down the substitution between workers of different ages, this might have had an impact also on productivity, if young workers are more attuned with new technologies. Secondly, by allowing atypical workers with low pay and fragmented work careers to be inadequately covered, the new contribution-based system has set in motion a 'pension time bomb' when these people reach retirement age. This problem is especially severe for women, who are more exposed to the risk of fragmentation of careers because of a poor reconciliation policy (Simonazzi, 2015). Subsequent laws attempted to respond to these problems by gradually extending the coverage to larger sections of atypical workers and re-introducing some flexibility in retirement age.

The interaction between the crisis and the labour and pension reforms has produced conflicting effects on the female employment rate. While occupational segregation sheltered women (relative to men) from the first effects of the crisis, subsequently female employment has suffered the effects of the fiscal crisis 
because of an over-representation in public sector employment. While the pension reform forcibly sustained the employment rate of older women, overall the crisis has brought the slowly increasing long-term trend of the female participation rate (which is still far behind the European average) to a halt.

To conclude, since the crisis growth eluded expectations, unemployment grew as did precariousness and insecurity. Income inequality and poverty increased. Social expenditure and social investment (education, research and development, health and care, training and active labour market policies) have all been drastically curtailed because of the fiscal compact. While real earnings stalled and mobility among income classes may not have decreased substantially, intergenerational mobility - measured across occupational groups (Simonazzi and Barbieri, 2016) and income groups (Franzini and Raitano, 2013) - has certainly decreased. The next section briefly discusses the long-term impact on growth.

\section{Flexibility, productivity and growth}

Structural reforms have their roots in the approach of mainstream economic theory that links the market mechanism with efficiency and productivity. According to this view, the problem with 'crisis countries' is a lack of cost competitiveness owing to excessive wage and labour protection. In 2004, the OECD Employment Outlook (OECD, 2004: 63) argued that a reasonable degree of EPL 'may foster long-term employment relationships, thus promoting workers' effort, co-operation and willingness to be trained, which is positive for aggregate employment and economic efficiency'. However, the 2016 OECD Employment Outlook (OECD, 2016) turned this argument on its head; well-designed structural reforms of product and labour markets may entail costly adjustments in the short run, but in the long-run the greater productivity of a more efficient allocation of labour will prevail again. Micro-economic factors buttress the long-run relationship (for a survey of the empirical research, see Boeri et al., 2015). In fact, by increasing firms' costs of dismissal, employment protection has a negative impact on productivity at the firm level: it lowers workers' effort (poor work performance or absenteeism) because there is less threat of lay-off, and it discourages firms from experimenting with new technologies with higher mean returns but also higher variance. The report concludes that the high employment and wage losses associated with greater flexibility in regulation governing the dismissal of workers on regular (openended) contracts would be reversed in a few years. The short-run costs are claimed to be less acute in countries with significant labour market dualism 
(measured as the share of fixed-term employment in total employment), and they would be smaller if reforms are implemented in the upswing, though it is in a depression that they are politically more enforceable (OECD, 2016). This view has legitimised the inclusion of structural reforms as a pre-condition in any agreements between the European Commission (EC) and programme or crisis member countries.

The results of these studies have not gone unchallenged. The short-run costs have been re-assessed and found to be neither small nor transitory, even for flexible labour markets such as the US one (Autor et al., 2016). The analysis of long-term effects of labour reforms on productivity and growth has been challenged on two grounds. Firstly, the model is based on the hypothesis of a smooth and efficient reallocation of labour. The assumption of a (full) employment equilibrium pre-empts any serious consideration of the costs of adjustment. Secondly, a truly dynamic analysis must consider the effects of employment relations on the factors determining innovation and competition. Specifically, competition increasingly relies on the quality and complexity of products, rather than on their price (Simonazzi et al., 2013). To be successful, firms must innovate their products, processes and organisation. To this end, a skilled and cooperative workforce is as essential as the firm's commitment to invest in its labour force. If arm's-length labour relations can make cost competitiveness profitable in the short run, this strategy may not pay in the long run. An increasing stream of literature has supported the view that labour market institutions that favour cooperation between workers and firms prove essential in sustaining growth and innovation (Addison et al., 2015; Fana et al., 2016). ${ }^{7}$ The Italian experience provides support to this view, even if on the negative side. Concern for 'excessive' regulation of the labour market has diverted attention from the structural problems at the origins of the stagnation of the Italian economy. Deregulation of the labour market has been preferred to an alternative strategy based on investing in people in combination with an industrial policy aimed at strengthening and upgrading the industrial structure. The result has been slow growth and stagnant productivity, a segmented labour market and an impoverished workforce.

Deregulation and austerity policies in Italy have impacted on macroeconomic performance also via their effects on income inequality. The unions' weakened bargaining power has resulted in low or negative real wages. More decentralised and individualised wage settings have increased wage dispersion and polarisation. Together, these factors have affected the rate of growth of domestic demand (consumption and investment). With the fiscal compact barring public expenditures, only exports have been left to counter the recession. By sustaining the share of wages and reducing inequality, industrial relations targeting a 
more equal society might have contributed to economic sustainability, thereby sustaining growth.

\section{Conclusions}

Since the crisis, within the European Monetary Union framework, austerity measures and structural reforms (i.e. labour and wage flexibility) have been the only instruments admitted to address macroeconomic imbalances. Drastic cuts in social investment and 'internal devaluations' have magnified the dualism in the labour market and increased inequality and poverty. The Italian experience does not support the view that, if sufficiently flexible, labour markets adjust quickly to shocks, so that, in the long run, the benefits of flexibility outweigh the short-run adjustment costs.

No degree of labour flexibility can provide an adequate response to the multiple challenges represented by technological, organisational and social changes. These changes call for coordinated responses in the production, employment and social spheres. The diverse experiences of European countries over the recent decades highlight the role of social policy as a productive factor. In Sweden, technological change has been tackled within a cooperative climate in industrial relations; new forms of work organisation and generous policies favouring the upgrading of skills and the improvement in the quality of work have turned the challenge of technical change into an opportunity (Anxo, 2016). Conversely, Germany seems to have co-opted only one part of the labour force, leaving a large proportion of low-skilled or fragile workers behind (Lehndorff, 2015). Finally, in the Southern European countries, the structural reforms implemented in the crisis have eroded labour rights and weakened labour unions, reinforcing a 'low road' of wage cuts and precarious work that has priced out any alternative attempt of profiting from technological innovation. Wage moderation and low wages could not counter the effects of productivity decline; on the contrary, they are at the root of the productivity problem (Ciccarone and Saltari, 2015; Tronti, 2013).

This chapter has argued in favour of a different model in which unions, firms and the state can interact to devise a long-term industrial policy capable of fostering those organisational changes and those patterns of innovation that better respond to a shared social model. This calls for a complete reboot of the European and national approaches towards macroeconomic, labour and social policies. 


\section{Notes}

1 See Schulten and Muller (2014) for an analysis of labour market deregulation policies in the EU.

2 'These contractual arrangements ... provide a contractual framework for individuals who are not formally employees of the firm and yet provide their regular working services (material or immaterial - i.e. consultants) to firms that often utilize them as normal employees. Compulsory pension and other social contributions are lower for these workers, which makes their labour costs lower than those of regular employees. As a result, many firms make great use of this type of arrangement' (ILO, 2015: 33).

3 See the confidential letter sent on 5 August 2011 by European Central Bank (ECB) President Jean-Claude Trichet and his designated successor, Bank of Italy Governor Mario Draghi, to the Italian head of government, demanding fiscal tightening and sweeping reforms before the ECB stepped into the market to ease mounting pressure on Italian bonds (Il Sole 24 Ore, http://24o.it/eHYLu).

4 This law protected workers from invalid lay-offs, requiring reinstatement in several cases. Law 92/2012 weakened this protection but did not completely abolish it. For a considerable set of cases, in fact, both the obligation of recourse to the courts in case of disputes over a dismissal and the possibility of workers' reinstatement were preserved.

5 Specific exceptions permitted by the law and sectoral collective agreements can allow deviation from this rule.

6 For detailed information, see: http://www.nuovi-lavori.it/index.php/sezioni/504-

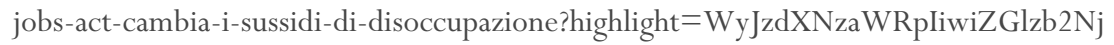
dXBhemlvbmUiXQ.

7 Differences in systems of innovations and industrial relations can explain differences in empirical results. For instance, it is argued that in the US skills are scouted mostly in the market, while in the European systems they are chiefly nurtured within the firm. This difference may explain why the empirical literature has found that firms' innovative dynamics are associated with centralised bargaining systems in the European economies (Addison et al., 2015) and with decentralised bargaining mechanisms and flexible labour markets in the USA (Menezes-Filho and Van Reenen, 2003). See Fana and colleagues (2016) for a review.

\section{References}

Addison, J. T., Teixeira, P., Evers, K. and Bellmann, L. (2015), Collective Bargaining and Innovation in Germany: Cooperative Industrial Relations?, IZA Discussion Paper Series No. 7871 (Bonn: Institute for the Study of Labor).

Anxo, D. (2016), 'Upskilling to avoid jobs' polarisation and growing income inequalities: the Swedish experience', Economia \& Lavoro, 50:2, 13-24. 
Autor, D. H., Dorn, D. and Hanson. G. H. (2016), The China Shock: Learning from Labor Market Adjustment to Large Changes in Trade, NBER Working Paper, No. 21906 (Cambridge, MA: National Bureau of Economic Research).

Blundell, R., Crawford, C. and Wenchao, J. (2014), 'What can wages and employment tell us about the UK's productivity puzzle?', The Economic Journal, 124:576, 377-407.

Boeri, T., Cahuc, P. and Zylberberg, A. (2015), The Costs of Flexibility-Enhancing Structural Reforms. A Literature Review, OECD Economic Department Working Papers, http:// www.oecd-ilibrary.org/economics/the-costs-of-flexibility-enhancing-structural-re forms_5jrs558c5r5f-en, accessed 18 March 2017.

Bosch, G., Lehndorff, S. and Rubery, J. (2009), 'European employment models in flux: pressures for change and prospects for survival and revitalization', in Bosch, G., Lehndorff, S. and Rubery, J. (eds), European Employment Models in Flux (London: Palgrave Macmillan), pp. 1-56.

Checchi, D. and Leonardi, M. (2015), Labour Market Measures in Italy 2008-13: The Crisis and Beyond (Geneva: International Labour Organization).

Ciccarone, G. and Saltari, E. (2015), 'Cyclical downturn or structural disease? The decline of the Italian economy in the last twenty years', Journal of Modern Italian Studies, 20:2, 228-44.

Contini B. and Trivellato U. (2005), 'Dinamiche e persistenze nel mercato del lavoro italiano: una sintesi', in Contini B. and Tivellato U. (eds), Eppur si muove (Bologna: Il Mulino), pp. 13-84.

Fana, M., Guarascio, D., and Cirillo, V. (2016), 'Did Italy need more labor flexibility? The consequences of the jobs act'. Intereconomics, 51:2, 79-86.

Franzini, M. and Raitano, M. (2013), 'Economic inequality and its impact on intergenerational mobility', Intereconomics, 48:6, 328-35.

Hyman, R. (2015), 'L'austeritarismo e l'Europa: quali vie per resistergli', Quaderni Rassegna Sindacale, 3, 65-110.

ILO (International Labour Organization) (2015), Inventory of Labour Market Policy Measures in the EU 2008-13: The Crisis and Beyond, Synthesis report (Geneva: International Labour Organization).

Istat (Istituto Italiano di Statistica) (2015), Rapporto annuale (Rome: Istat).

Istat (Istituto Italiano di Statistica) (2016a), Rapporto annuale (Rome: Istat).

Istat (Istituto Italiano di Statistica) (2016b), Il mercato del lavoro, 12 September, http:// www.istat.it/it/files/2016/09/Mercato-del-lavoro-II-trim_2016.pdf?title=Il+me rcato+del+lavoro+_+12\%2Fset\%2F2016+-+Testo+integrale+e+nota+metodolog ica.pdf, accessed 18 March 2017.

Lehndorff, S. (2015), 'Model or liability? The new career of the "German model"', in Lehndorff, S. (ed.), Divisive Integration: The Triumph of Failed Ideas in Europe - Revisited (Brussels: European Trade Union Institute).

Leonardi, S. (2016), 'Trade Unions and collective bargaining in Italy in the years of the crisis'. Forthcoming in Lehndorff, S., Dribbusch, H. and Schulten, T. (eds.), A Rough Landscape - European Trade Unions in Times of Crises (Brussels: European Trade Union Institute). 
Menezes-Filho, N. and Van Reenen, J. (2003), 'Unions and innovation: a survey of the theory and empirical evidence', in Addison, J. T. and Schnabel, C. (eds), International Handbook of Trade Unions (Cheltenham: Edward Elgar), pp. 293-334.

OECD (Organisation for Economic Co-operation and Development) (1994), The Jobs Study (Paris: OECD).

OECD (Organisation for Economic Co-operation and Development) (2004), Employment Outlook (Paris: OECD), http://www.oecd.org/els/emp/34846856.pdf.

OECD (Organisation for Economic Co-operation and Development) (2016), How Good Is Your Job? Measuring and Assessing Job Quality (Paris: OECD), http://www.oecd.org/std/ labour-stats/Job-quality-OECD.pdf, accessed 18 March 2017.

OECD (Organisation for Economic Co-operation and Development) (2017), Indicators of Employment Protection (Paris: OECD), http://www.oecd.org/employment/emp/ oecdindicatorsofemploymentprotection.htm, accessed 18 March 2017.

Rubery, J. (2015), Re-regulating for Inclusive Labour Markets, Conditions of Work and Employment Series No. 65 (Geneva: International Labour Organization).

Rubery, J. and Piasna, A. (2016), Labour Market Segmentation and the EU Reform Agenda: Developing Alternatives to the Mainstream, Working Paper No. 10 (Brussels: European Trade Union Institute).

Schulten, T. and Müller, T. (2014), 'European economic governance and its intervention in national wage development and collective bargaining', in Lehndorff, S. (ed.), Divisive Integration: The Triumph of Failed Ideas in Europe - Revisited (Brussels: European Trade Union Institute), pp. 331-63.

Sestito, P. and Viviano, E. (2016), 'Hiring incentives and/or firing cost reduction? Evaluating the impact of the 2015 policies on the Italian labour market', Questioni di Economia e Finanza, 325.

Simonazzi, A. (2015), 'Italy: continuity and change in welfare state retrenchment', in Vaughan-Whitehead, D. (ed.), The European Social Model in Crisis: Is Europe Losing its Soul? (Cheltenham: Edward Elgar and Geneva: International Labour Organization), pp. 339-85.

Simonazzi, A. and Barbieri, T. (2016), 'The middle class in Italy: reshuffling, erosion, polarization', in Vaughan-Whitehead, D. (ed.), European Middle class Disappearing - Evidence in the World of Work (Cheltenham: Edward Elgar and Geneva: International Labour Organization), pp. 245-70.

Simonazzi, A., Ginzburg, A. and Nocella, G. (2013), 'Economic relations between Germany and southern Europe,' Cambridge Journal of Economics, 37:3, 653-75.

Simonazzi, A. and Villa, P. (2007), 'Le stagioni della vita lavorativa e il tramonto del 'sogno americano' delle famiglie italiane', in Villa, P. (a cura di) Generazioni flessibili (Roma: Carocci Editore).

Tronti, L. (2013), 'Riforme della contrattazione, produttività e crescita: un dialogo tra economisti’, Economia \& Lavoro, 47:3, 7-70. 